\title{
Increasy eutrophication symptoms during a prolonged drought event in tropical semi-arid reservoirs, Brazil
}

\section{Aumento dos sintomas de eutroficação durante um evento de seca prolongada em reservatórios semiáridos tropicais, Brasil}

\author{
Diógenes Fernandes dos Santos ${ }^{1}$ (D), Jonathan Mota da Silva ${ }^{1}$ (D) \& Vanessa Becker ${ }^{1}$ \\ ${ }^{1}$ Universidade Federal do Rio Grande do Norte, Natal, RN, Brasil \\ E-mails: diogenes.fernandes.santos@gmail.com (DFS), jonathanmota.ufrn@gmail.com (JMS), becker.vs@gmail.com (VB)
}

Received: July 01, 2021 - Revised: November 09, 2021 - Accepted: November 10, 2021

\begin{abstract}
Eutrophication is a global problem and an important cause of the ecological health degradation of aquatic ecosystems. The aim was to evaluate the effect of prolonged drought period (2012 to 2019) on the trophic state of two Brazilian semi-arid reservoirs, Boqueirão de Parelhas (BOQ) and Passagem das Traíras (TRA). The work was carried out according to a drought classification system, based on the Standardized Precipitation Index (SPI), with an aggregated timescale of 36 months, defining three periods. In the Period I, higher values of Secchi and lower values of turbidity, solids, nutrients and chlorophyll-a were registered, when compared to the other periods, mainly in BOQ. The principal component analyses of both reservoirs reveled a showed a temporal trend of the sample units according to the consequences of the prolonged drought. The results indicated changes in limnological variables due to the reduction of accumulated water volume, and they demonstrated that prolonged droughts impact the intensification of eutrophication in both systems. The trophic state of the BOQ reservoir was changed from mesotrophic to eutrophic as a consequence of the drought, while in TRA the eutrophic state remained, but with more intensified symptoms, with higher concentration values of nutrients, solids and algal biomass.
\end{abstract}

Keywords: Hydric deficit; Water quality; Drylands; Standardized precipitation index.

\section{RESUMO}

A eutrofização é um problema global e uma importante causa da degradação da saúde ecológica dos ecossistemas aquáticos. O objetivo foi avaliar o efeito do período prolongado de seca sobre o estado trófico de dois reservatórios semiáridos brasileiros, Boqueirão de Parelhas (BOQ) e Passagem das Traíras (TRA). O trabalho foi realizado de acordo com um sistema de classificação de secas, com base no Índice Padronizado de Precipitação (SPI), com uma escala de tempo agregada de 36 mese definindo três períodos. No Período I, maiores valores de Secchi e menores valores de turbidez, sólidos suspensos totais, fósforo total e clorofila-a foram registrados quando comparados aos demais períodos, principalmente em BOQ. As análises de componentes principais de ambos os reservatórios revelaram uma tendência temporal das unidades amostrais de acordo com as consequências da seca prolongada. Os resultados indicaram mudanças nas variáveis limnológicas devido à redução do volume de água, e demonstraram que secas prolongadas impactam na intensificação da eutrofização em ambos sistemas. O estado trófico do BOQ foi alterado de mesotrófico para eutrófico como uma consequência da seca, enquanto que em TRA o estado eutrófico permaneceu, mas com os sintomas intensificados, com altas concentrações de nutrientes, sólidos e biomassa algal.

Palavras-chave: Défict hídrico; Qualidade da água; Terras secas; Índice de precipitação padronizado. 


\section{INTRODUCTION}

Eutrophication is the process of the excessive accumulation of nutrients (nitrogen and phosphorus), resulting in a high primary productivity, loss of ecological balance, and progressive degradation of the aquatic ecosystem (Schindler, 2006; Moal et al., 2019). As a result of this process, there is an increase in algal biomass and turbidity, a reduction of transparency, changes in the color and odor of the water, and a decrease in the concentration of dissolved oxygen (Dodds et al., 2009).

Cultural eutrophication, result of anthropogenic activities, was described decades ago and currently still represents an expanding phenomenon (Smith \& Schindler, 2009; Moal et al., 2019). This process is, therefore, the result of poor management of water resources, in which it must meet the growing demand demanded by the global increase in the human population and also support discharges of domestic, industrial and agricultural effluents (Tundisi \& Matsumura-Tundisi, 1992).

Hydrological and climatic factors play important roles in water levels and the water residence time, directly affecting the water quality of the reservoirs (Naselli-Flores \& Barone, 2005; Soares et al., 2012; Jeppesen et al., 2015). These changes can modify the trophic state (Naselli-Flores \& Barone, 2003; Rocha et al., 2018; Wiegand et al., 2021).

In several studies of projections of future precipitation changes over Brazil (derived from global and regional climate models), scientists have found a consistent pattern of droughts in the northeastern part of the country (Alves et al., 2021). These create hydrological stressors in aquatic ecosystems, especially in arid and semiarid regions (Jeppesen et al., 2009; Roland et al., 2012; Marengo et al., 2016).

The effects of precipitation variability on water quality can be due to the combination of two mechanisms: the higher concentration of nutrients in periods of drought, mainly due to the reduction in water volume; and an increase in allochthonous material during periods of sporadic heavy rains (Nobre et al., 2020). Prolonged drought events, intensified by climate change, negatively affect water quality (Moss et al., 2011). Droughts are conditioned by the occurrence of El Nino, but the observation of more extreme climatic variability in the last five decades reveals that its incidence and consequences are linked to human action (Viana, 2013). The overlapping of droughts with pre-existing socioeconomic and political issues puts great pressure on the availability and quality of freshwater in the region. It strongly threatens water, energy, and food security as well (Gutiérrez et al., 2014). Droughts, in particular, are expected to increase in frequency and intensity in northeastern Brazil due to climate change, especially in the semiarid region (World Bank, 2013). This region is vulnerable to the extremes of interannual climate variability (mainly droughts) and climate change scenarios, indicating that it will be affected by rainfall deficits and increased aridity in the second half of the 21st century (Intergovernmental Panel on Climate Change, 2014; Marengo \& Bernasconi, 2015).

Nowadays, these events can already be observed. The drought of 2012 to 2016 was the more intense of the last 60 years, according to the Agência Nacional de Águas (2016), and it has had impacts on many districts in the semiarid regions of the states of northeastern Brazil, affecting almost 9 million people (Marengo et al., 2013,
2018, 2020; Cunha et al., 2019; Centro Nacional de Monitoramento e Alertas de Desastres Naturais, 2019; Bravo et al., 2021). As a result, the drought that affected the Brazilian semiarid region had a negative impact on human water supply and agriculture with an intensity that was not seen in the previous decades (Alvalá et al., 2017). Rainfall variability, land degradation, desertification, and socioeconomic characteristics are some of the factors that, if combined, could make this region one of the world's most vulnerable to climate change (Intergovernmental Panel on Climate Change, 2014). In this sense, studies indicate that the semiarid region has already shown symptoms of intensification of eutrophication due to these extreme drought events, increasing the concentration of nutrients, conductivity, solids and algal biomass (Brasil et al., 2016; Costa et al., 2016; Figueiredo \& Becker, 2018; Rocha et al., 2018). Furthermore, the decrease in water volume in these dry periods favors the blooms of potentially toxic cyanobacteria (Bouvy et al., 1999; Costa et al., 2019, Medeiros et al., 2015, Vanderley et al., 2021).

Despite these studies in the semiarid region, little is reported on a larger time scale. Thus, even though a descriptive study and there being some publications on the theme of water quality and drought in the Brazilian semiarid region, our work has an important time scale, which encompasses this prolonged drought in the region that lasted eight (08) consecutive years, from 2012 to 2019 (Alvalá et al., 2017; Centro Nacional de Monitoramento e Alertas de Desastres Naturais, 2019).

In this study, we assessed the prolonged drought impacts on the reservoirs water quality in the semiarid tropical region, verifying changes in the trophic state. The hypothesis of the work was that there is an intensification of the trophic state of the reservoirs due to extreme drought events. Under ideal conditions throughout the year (ie, lack of rainfall, high light and temperature), droughts can intensify the risk and variety of problems associated with eutrophication.

\section{MATERIALS AND METHODS}

\section{Study area}

The reservoirs that were studied are located in the semiarid region of Rio Grande do Norte State (northeast Brazil), in the hydrographic basin of the Piranhas-Açu River (Figure 1): Boqueirão de Parelhas (6 $41^{\prime} 15^{\prime \prime}$ S; 36 $46^{\circ}$ '15" W) located in Parelhas City, and Passagem das Traíras (6 $6^{\circ} 27^{\prime} 16^{\prime \prime}$ S; 36 52'29” W) in São José do Seridó City.

The Boqueirão de Parelhas reservoir was built in 1988, whereas Passagem das Traíras reservoir was in 1994. Boqueirão de Parelhas has a maximum accumulation capacity of $84,792,119.23 \mathrm{~m}^{3}$, comprising an area of 1267.27 ha with a maximum design depth of 29 meters (Secretaria de Estado do Meio Ambiente e dos Recursos Hídricos do Rio Grande do Norte, 2019). Passagem das Traíras has a maximum accumulation capacity of $49,702,393.65 \mathrm{~m}^{3}$, covering an area of 1042.90 ha with a maximum depth of 25.5 meters (Secretaria de Estado do Meio Ambiente e dos Recursos Hídricos do Rio Grande do Norte, 2019). The reservoirs are mostly used to human water supply, feed animals, irrigate, and provide recreation. Both 

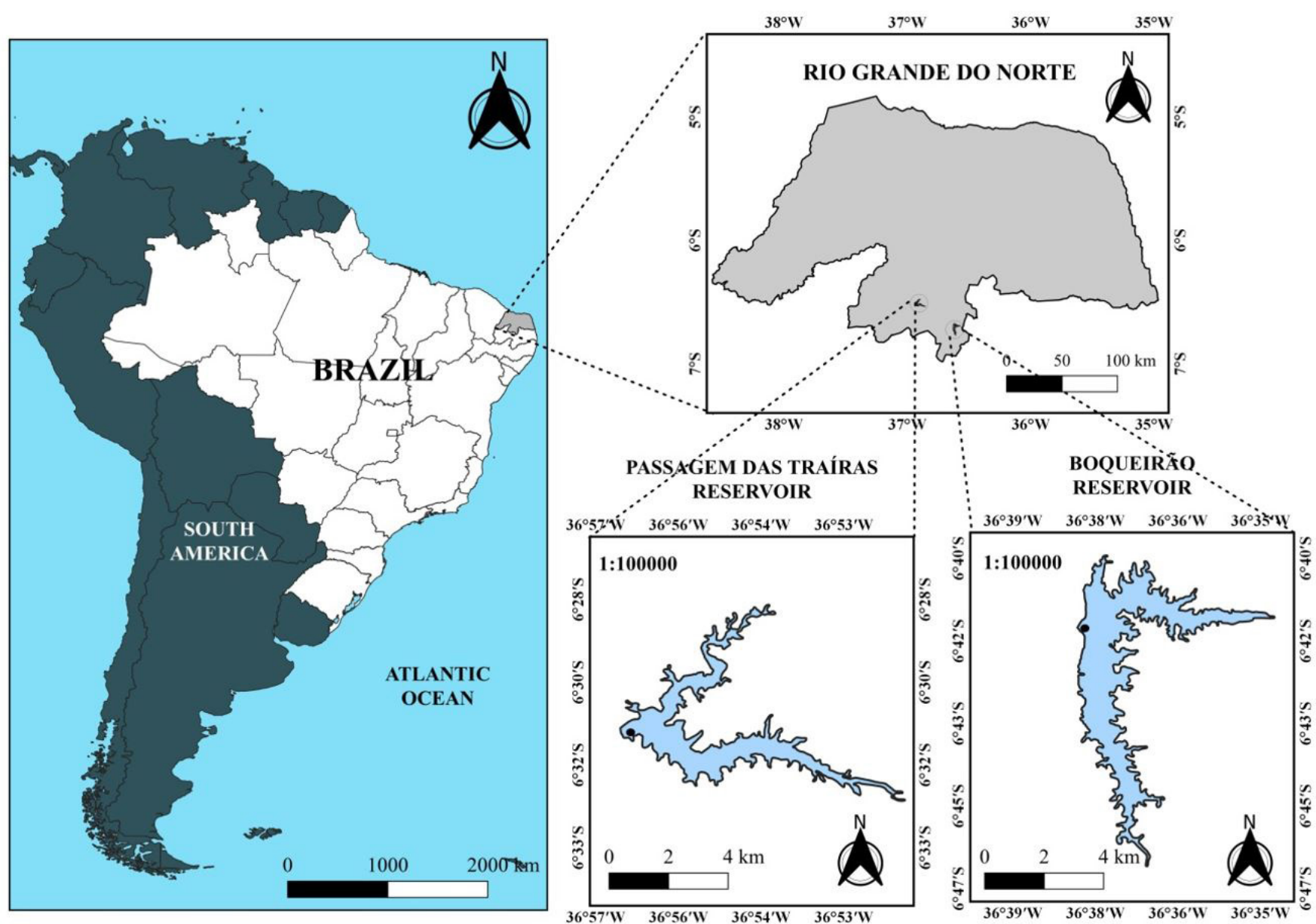

Figure 1. The geographic location of Rio Grande do Norte State (in gray) in northeast Brazil, and the reservoirs shape (A) Passagem das Traíras and (B) Boqueirão de Parelhas, indicating the sampling point $(\bullet)$.

reservoirs are located in a rural area, with little urbanization zone. In this region, the diffuse pollution, resulting from agriculture and livestock, seems to be the external loading of nutrients (Medeiros, 2016; Cavalcante et al., 2017). In addition, internal loading is the source that maintains the high algal biomass during drought periods, characterized by the intermittent rivers in the region, especially in Boqueirão de Parelhas (Cavalcante et al., 2021).

The region where the reservoirs are located has a semiarid tropical climate of low latitudes and altitude -BS'h (Alvares et al., 2014), with annual precipitation between $200 \mathrm{~mm}$ to $650 \mathrm{~mm}$ per year, which is at its maximum during summer and autumn. The highest accumulated precipitation ( $319 \mathrm{~mm}$ ) occurs from March to May (Reboita et al., 2010; Oliveira et al., 2016). A significant part of these rains occurs in late summer and early autumn, influenced by the Intertropical Convergence Zone (ZCIT) associated with the convergence of humidity (Reboita et al. 2010, Molion \& Bernardo, 2002). The years with the highest rainfall totals occur when the ZCIT reaches its southernmost position during summer and autumn (Melo et al., 2009). Remnants of the frontal systems that reach the Brazilian semiarid region (Reboita et al., 2010; Molion \& Bernardo, 2002) and Upper Tropospheric Cyclonic Vortices (Reboita et al., 2010; Kousky \& Gan, 1981; Morais et al. 2020), notably during the southern summer (depending on its location) also form the dynamic mechanisms responsible for the rain in the region.

\section{Sampling}

Water samples were collected every month at the sampling point (Figure 1), near by the dam and water intake, the deepest point in the reservoirs. This study was designed to address three periods: January 2012 to December 2012; January 2014 to December 2014; and June 2018 to May 2019.

The water samples were integrated into the epilimnion using a vertical Van Dorn bottle. Epilimnion was determined from vertical dissolved oxygen and temperature profiles. The profiles were measured using a multiparametric probe (Hidrolab DS5) from 2012 to 2014, and with a portable oximeter (Instrutherm MO-900) during the years 2018 and 2019. The water transparency was measured by a Secchi disk.

The samples for ammonia analysis were stored in an amber bottle and the other samples were stored in polyethylene bottles. Both were previously washed with $10 \%$ hydrochloric acid (HCL) 
and deionized water, and they were also stored in thermal boxes with ice during transport until carrying out the analyses.

\section{Sample analysis}

In the laboratory, the turbidity (TURB) was measured using a turbidimeter (PoliControl AP2000), and the electrical conductivity (EC) was measured by the use of a conductivity meter (Tec-4MP). Total phosphorus (TP) was analyzed by the ascorbic acid method after oxidation with potassium persulfate (Valderrama, 1981). The ammonium ion $\left(\mathrm{NH}_{4}^{+}\right)$was determined by employment of the colorimetric method through nesslerization (American Public Health Association, 2005).

For inorganic nutrients, the water samples were filtered through fiberglass filters $(0=47 \mathrm{~mm}$; porosity of $1.2 \mu \mathrm{m})$. Subsequent to that was the carrying out of the analysis of soluble reactive phosphorus (SRP) by using the ascorbic acid method (Murphy \& Rilley, 1962), as well as nitrate $\left(\mathrm{NO}_{3}^{-}\right)$, using sodium salicylate (Muller \& Widemann, 1955). Both analyses were measured by spectrophotometry. The filters were used for the analysis of total suspended solids (TSS) and chlorophyll-a (Chl-a). The TSS was determined by gravimetric method, after drying the filters overnight at $100{ }^{\circ} \mathrm{C}$ (American Public Health Association, 2012). Chl-a was extracted with $95 \%$ ethanol and measured by spectrophotometry (Jespersen \& Christoffersen, 1987). The concentrations of dissolved inorganic nitrogen (DIN) were determined from the sum of the concentrations of $\mathrm{NH}_{4}^{+}$and $\mathrm{NO}_{3}$.

\section{Data analysis}

Data on monthly rainfall were provided by the Agricultural Research Corporation of the state of Rio Grande do Norte (EMPARN). Based on this information the Standardized Precipitation Index - SPI (McKee et al., 1993) was calculated with the aid of Software R (SPEI package). The SPI is based on the probability of precipitation for different timescales and can be used to classify droughts. The drought categories include mild drought, moderate drought, severe drought, and extreme drought (Table 1).

The monthly drought classification for Boqueirão and Passagem das Traíras followed the SPI classifications (Santos, 2020). Thus, the months of our study were subdivided into periods according to the SPI, calculated based on precipitation (McKee et al., 1993) with an aggregated timescale of 36 months (SPI-36). This timescale was the best correlated with the time needed for the effects of the drought to be felt in the volume of the reservoirs (Santos, 2020).

Table 1. Drought categories (Gummus \& Algin 2017), adapted.

\begin{tabular}{cc}
\hline SPI CLASSES & $\begin{array}{c}\text { Classification of } \\
\text { Drought }\end{array}$ \\
\hline SPI $\leq-2$ & Extreme Drought \\
$-2<$ SPI $\leq-1,5$ & Severe Drought \\
$-1,5<$ SPI $\leq-1$ & Moderate Drought \\
$-1<\mathrm{SPI} \leq 0$ & Mild Drought \\
\hline
\end{tabular}

Thus, the periods were categorized by SPI-36, and were denoted as Period I (P I), the beginning of the drought, representing the mild drought (January 2012 to December 2012); Period II (P II) representing the extreme/ severe drought scenario (January 2014 to December 2014); and Period III (P III) with mild drought (June 2018 to May 2019).

The accumulated water volume measurements of the reservoirs throughout the study period were provided by the Rio Grande do Norte Water Management Institute (IGARN) and the State Secretariat of Water Resources of Rio Grande do Norte (SEMARH).

Classification of the trophic state addressed in this work was based on the values of the concentrations of TP and Chl-a to categorize the trophic state of the reservoir, according to Thornton \& Rast (1993): Mesotrophic (TP $<50 \mu \mathrm{g} . \mathrm{L}^{-1}$ and Chl-a $<15 \mu$ g.L $\left.\mathrm{L}^{-1}\right)$; Eutrophic (TP > $50 \mu \mathrm{g} . \mathrm{L}^{-1}$ and Chl-a $>15 \mu \mathrm{g} . \mathrm{L}^{-1}$ ).

The nonparametric Kruskal-Wallis test was employed to determine differences in water quality variables among the three periods and the reservoirs. The post hoc test used was Fisher's minimum significant difference criterion. The alpha parameter was 0.05. The correction adjustment method used was Bonferroni. Data analyses were performed using the statistical software $\mathrm{R}$ 'agricolae' package (De Mendiburu, 2021).

Descriptive analyses of limnological and hydrological variables were performed. Principal Component Analysis (PCA) was used to verify temporal gradients of the sample units, water volume, and limnological variables in relationship to the severity of the drought, using PcORD® v.6 (Mccune \& Mefford, 2011). For the ordination analysis, the data were transformed by $\log \mathrm{x}+1$.

To obtain shapefiles showing the drainage and water area during each monitored period. Thus, a supervised classification was carried out using satellite images from LANDASAT 7 and 8. Satellite images were obtained from the Earth Explorer site of the United States Geological Survey (USGS). Furthermore, Google Earth was used to help identify the water present in each period presented.

\section{RESULTS}

\section{Meteorological and hydrological scenarios}

For the Boqueirão de Parelhas reservoir, Period I was registered as a time of mild drought, however, in the first seven months of the year there was no drought. Period II was classified as a time of severe to extreme drought, and Period III was categorized as a time of mild drought (Figure 2).

For the reservoir of Passagem das Traíras, Period I was mostly categorized as a time of mild drought, however in the first four months of the year there was no drought. During Period II, the classification of drought was from moderate to severe, reaching the classification of extreme drought; and Period III was classified as a time of mild drought (Figure 2).

At the beginning of the study, in both reservoirs the water volumes were around 60\% accumulation (2012). Throughout the study, the drought intensified, becoming categorized as severe to 

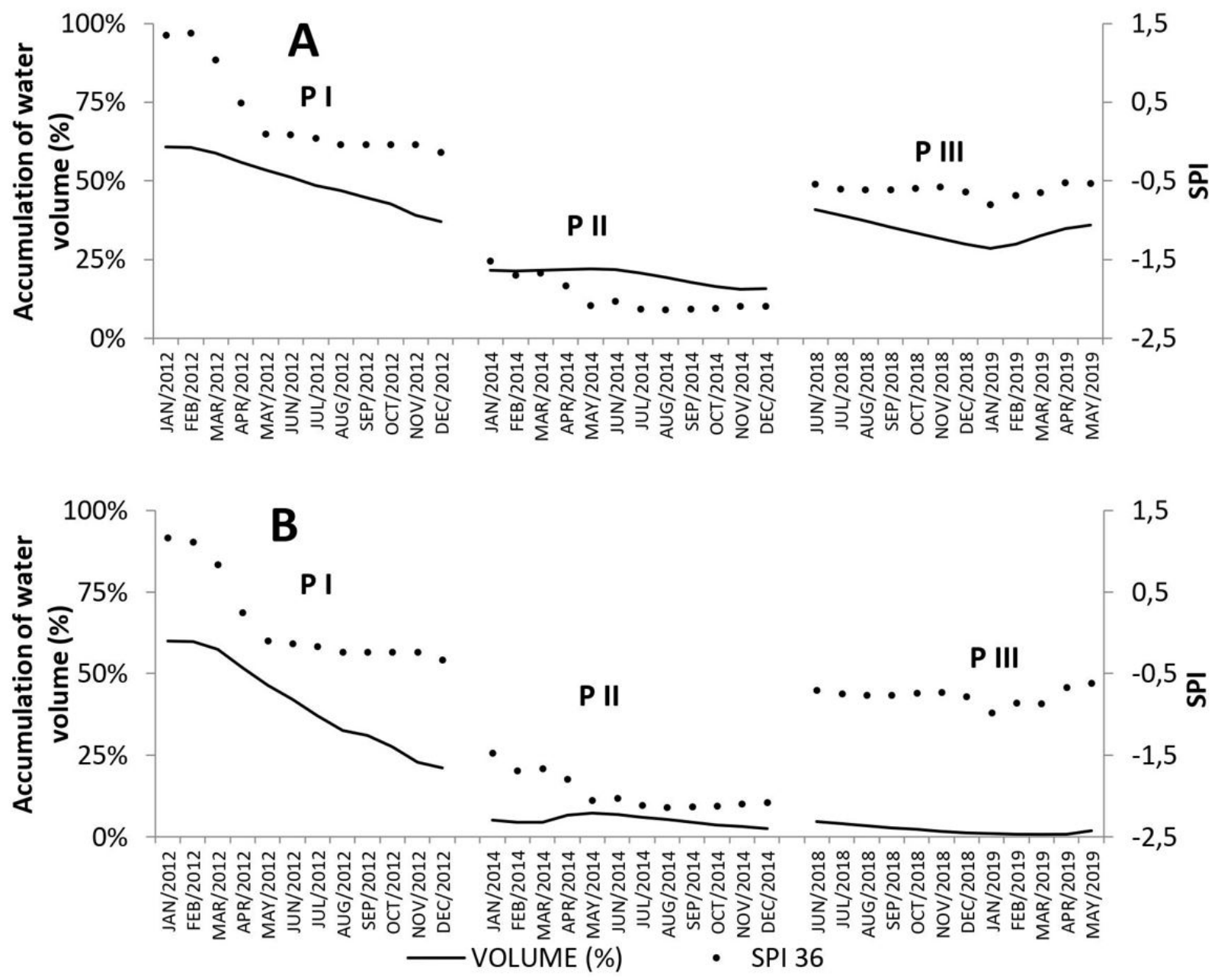

Figure 2. Accumulation of the monthly water volume (\%) in the P I, P II and P III Periods of the reservoirs, and the standardized precipitation index for thirty-six months - SPI36. (A) Boqueirão de Parelhas; (B) Passagem das Traíras. P I= Period I. P II= Period II and P III = Period III.

extreme in 2014 (Figure 2). In Period III the drought was categorized as mild for both water sources, but only Boqueirão de Parelhas was able to slightly recover its accumulated water volume, reaching about $36 \%$ of its volume by the end of the study (Figure 2).

In Period I, in both reservoirs, the water volume had the highest medians (Table 2). In all three periods, the Passagem das Traíras reservoir had a lower percentage of maximum volume storage (Table 2). In the Period I, the Boqueirão de Parelhas reservoir (BOQ) displayed higher values of water volume (Figure 3), differed significantly $(\mathrm{p}<0.05$, Kruskal-Wallis test) from Passagem das Traíras (TRA). Over the other periods studied (II and III), there was a gradual decrease in water volume for BOQ, which was statistically different between periods (Figure 3). TRA also presented the same trend (Figure 3).

\section{Limnological scenario}

In the Period I, at the beginning of the drought, for BOQ, higher values of Secchi transparency (Secchi) and lower values of turbidity, total suspended solids (TSS), total phosphorus (TP) and chlorophyll-a (Chl-a) were presented, differed significantly $(\mathrm{p}<0.05)$ when compared to the other periods II and III), and also in relation to the TRA (Figure 3). For TRA there was a trend of increase in TSS concentrations and reduction of Secchi from period I to periods II and III (Figure 3), but they were not statistically different. Even for this reservoir the concentration of TP was lower in period I, being statistically different from the other periods, which recorded higher values and were not different from each other (Figure 3).

TURB (BOQ 18.1 NTU; TRA 39.5 NTU), TSS (BOQ 19.6 mg.L - $^{-1}$; TRA 43.0 mg.L-1 $)$, EC (BOQ $1998 \mu$ S.cm ${ }^{-1}$; TRA $39.5 \mu{\mathrm{S} . \mathrm{cm}^{-1}}^{-1}$ ), and DO (BOQ $8.05 \mathrm{mg} . \mathrm{L}^{-1}$; TRA $12.17 \mathrm{mg} . \mathrm{L}^{-1}$ ) presented higher median values during Period II, when severe drought/extreme drought was noted for both reservoirs (Table 2). Secchi depth showed the lowest median (BOQ $0.5 \mathrm{~m}$; TRA $0.20 \mathrm{~m}$ ) in Period II for both reservoirs (Table 2). TP (BOQ 88.7 $\mu$ g.L. $\mathrm{L}^{-1}$; TRA $258.4 \mu \mathrm{g} . \mathrm{L}^{-1}$ ) and SRP (BOQ $6.43 \mu \mathrm{g} . \mathrm{L}^{-1}$; TRA $\left.101.24 \mu \mathrm{g} . \mathrm{L}^{-1}\right)$ displayed higher median values in Period III for both reservoirs (Table 2). 
Table 2. Descriptive statistics (average, standard deviation, median, minimum, and maximum) of the limnological variables studied in the reservoirs during the study periods.

\begin{tabular}{|c|c|c|c|c|c|c|}
\hline \multirow[b]{2}{*}{ Variáveis } & \multicolumn{2}{|c|}{ Period I } & \multicolumn{2}{|c|}{ Period II } & \multicolumn{2}{|c|}{ Period III } \\
\hline & Boqueirão & $\begin{array}{c}\text { Passagem das } \\
\text { Traíras }\end{array}$ & Boqueirão & $\begin{array}{c}\text { Passagem das } \\
\text { Traíras }\end{array}$ & Boqueirão & $\begin{array}{c}\text { Passagem das } \\
\text { Traíras }\end{array}$ \\
\hline Volume $\left(10^{6} \mathrm{~m}^{3}\right)$ & $\begin{array}{c}41.13 \pm 7.4 ; 40.87 \\
(31.41-51.57)\end{array}$ & $\begin{array}{c}19.91 \pm 6.76 ; 19.61 \\
(10.46-29.82)\end{array}$ & $\begin{array}{c}16.04 \pm 2.42 ; 17 \\
(11.82-18.74)\end{array}$ & $\begin{array}{c}2.44 \pm 0.85 ; 2.34 \\
(1.14-3.74)\end{array}$ & $\begin{array}{c}28.96 \pm 3.27 ; 28.9 \\
(24.14-34.7)\end{array}$ & $\begin{array}{c}1.05 \pm 0.67 ; 0.88 \\
(0.37-2.33)\end{array}$ \\
\hline Secchi (m) & $\begin{array}{c}1.89 \pm 0.72 ; 1.99 \\
\quad(0.85-3.5)\end{array}$ & $\begin{array}{c}0.31 \pm 0.04 ; 0.3(0.23 \\
-0.4)\end{array}$ & $\begin{array}{c}0.5 \pm 0.09 ; 0.52(0.3 \\
-0.6)\end{array}$ & $\begin{array}{c}0.24 \pm 0.14 ; 0.2(0.12 \\
-0.61)\end{array}$ & $\begin{array}{l}0.65 \pm 0.18 ; 0.65 \\
\quad(0.35-0.95)\end{array}$ & $\begin{array}{l}0.44 \pm 0.22 ; 0.43 \\
\quad(0.12-0.8)\end{array}$ \\
\hline $\mathrm{EC}\left(\mu \mathrm{S} . \mathrm{cm}^{-1}\right)$ & $\begin{array}{c}1263 \pm 100 ; 1253 \\
(1131-1420)\end{array}$ & $\begin{array}{c}839 \pm 134 ; 826(660 \\
-1064)\end{array}$ & $\begin{array}{c}1948 \pm 233 ; 1998 \\
(1466-2210)\end{array}$ & $\begin{array}{l}1996 \pm 349 ; 2006 \\
(1326-2770)\end{array}$ & $\begin{array}{l}657.7 \pm 124.8 ; 711 \\
\quad(418-813)\end{array}$ & $\begin{array}{c}1225 \pm 478 ; 1173 \\
(474-1786)\end{array}$ \\
\hline $\mathrm{pH}$ & $\begin{array}{c}8.65 \pm 0.22 ; 8.69 \\
(8.31-8.96)\end{array}$ & $\begin{array}{l}8.83 \pm 0.37 ; 8.93 \\
\quad(8.12-9.36)\end{array}$ & $\begin{array}{c}9.21 \pm 0.76 ; 9.23(7.8 \\
-10.25)\end{array}$ & $\begin{array}{c}9.88 \pm 0.51 ; 9.99 \\
(8.65-10.51)\end{array}$ & $\begin{array}{c}8.22 \pm 0.56 ; 8.09 \\
\quad(7.57-9.32)\end{array}$ & $\begin{array}{l}8.36 \pm 0.35 ; 8.37 \\
\quad(7.73-8.74)\end{array}$ \\
\hline $\mathrm{DO}\left(\mathrm{mg} \cdot \mathrm{L}^{-1}\right)$ & $\begin{array}{c}7.74 \pm 1.09 ; 7.97 \\
(6.09-9.26)\end{array}$ & $\begin{array}{l}10.15 \pm 3.54 ; 9.05 \\
\quad(5.8-16.49)\end{array}$ & $\begin{array}{c}8.35 \pm 1.52 ; 8.05 \\
(6.27-11)\end{array}$ & $\begin{array}{c}12.81 \pm 3.47 ; 12.17 \\
(0-19.83)\end{array}$ & $\begin{array}{c}7.69 \pm 1.97 ; 7.85(3.7 \\
-11.1)\end{array}$ & $\begin{array}{c}8.3 \pm 1.4 ; 8.05(5.7 \\
-10.9)\end{array}$ \\
\hline Turb (NTU) & $\begin{array}{c}3.83 \pm 2.77 ; 3.0 \\
(1.26-11.4)\end{array}$ & $\begin{array}{c}32.76 \pm 12.4 ; 34.0 \\
\quad(14.4-49.1)\end{array}$ & $\begin{array}{c}17.41 \pm 7.59 ; 18.1 \\
(8-37)\end{array}$ & $\begin{array}{c}35.54 \pm 22.62 ; 39.5 \\
(6.8-72)\end{array}$ & $\begin{array}{c}17.19 \pm 7.99 ; 14.7 \\
(5.2-36.4)\end{array}$ & $\begin{array}{c}19.45 \pm 8.43 ; 17.3 \\
\quad(5.2-34)\end{array}$ \\
\hline TSS $\left(m g . L^{-1}\right)$ & $\begin{array}{c}7.23 \pm 6.69 ; 5.0(3.14 \\
-27.6)\end{array}$ & $\begin{array}{l}23.77 \pm 6.47 ; 23.4 \\
\quad(13.2-32.8)\end{array}$ & $\begin{array}{c}23.25 \pm 14.23 ; 19.6 \\
(12-66)\end{array}$ & $\begin{array}{c}41.29 \pm 14.79 ; 43.0 \\
(20-62)\end{array}$ & $\begin{array}{c}14.15 \pm 6.72 ; 13.7 \\
(4-23.25)\end{array}$ & $\begin{array}{c}28.22 \pm 14.33 ; 26.5 \\
(8-60)\end{array}$ \\
\hline $\mathrm{TP}\left(\mu \mathrm{g} \cdot \mathrm{L}^{-1}\right)$ & $\begin{array}{c}29.06 \pm 12.91 ; 30.3 \\
(6.83-54)\end{array}$ & $\begin{array}{c}116.76 \pm 44.63 ; \\
109.8(56.2-216)\end{array}$ & $\begin{array}{c}85.97 \pm 28.01 ; 73.83 \\
(57-134.83)\end{array}$ & $\begin{array}{c}297.9 \pm 124.5 ; 268.5 \\
(168-567)\end{array}$ & $\begin{array}{c}88.22 \pm 33.6 ; 88.7 \\
(32.4-144.67)\end{array}$ & $\begin{array}{c}317.7 \pm 214.2 ; 258.4 \\
(27.83-673)\end{array}$ \\
\hline $\mathrm{NO}_{3}\left(\mu \mathrm{g} \cdot \mathrm{L}^{-1}\right)$ & $\begin{array}{c}118.0 \pm 38.1 ; 109.2 \\
(59.5-174)\end{array}$ & $\begin{array}{c}126.17 \pm 66.55 \\
119.5(39.5-297)\end{array}$ & $\begin{array}{l}181.1 \pm 75.7 ; 172.7 \\
\quad(91.5-341.5)\end{array}$ & $\begin{array}{c}206.79 \pm 48.41 \\
200.5(132-298)\end{array}$ & $\begin{array}{c}303.3 \pm 654.4 ; 129.3 \\
(19-2376)\end{array}$ & $\begin{array}{l}203.9 \pm 125.6 ; 220.9 \\
\quad(29-472.5)\end{array}$ \\
\hline $\mathrm{NH}_{4}^{+}\left(\mu \mathrm{g} \cdot \mathrm{L}^{-1}\right)$ & $\begin{array}{c}487.9 \pm 253.2 ; 422.0 \\
(239-1159)\end{array}$ & $\begin{array}{c}1007 \pm 288 ; 991.7 \\
\quad(612-1429)\end{array}$ & $\begin{array}{c}189.3 \pm 69.5 ; 202.8 \\
(66.1-262.9)\end{array}$ & $\begin{array}{c}719.0 \pm 433 ; 638.3 \\
(376.0-2001.8)\end{array}$ & $\begin{array}{c}812.9 \pm 885 ; 421.3 \\
(27.9-2790.2)\end{array}$ & $\begin{array}{l}688.6 \pm 498.2 ; 634.1 \\
\quad(13.5-1685.1)\end{array}$ \\
\hline $\operatorname{SRP}\left(\mu g . L^{-1}\right)$ & $\begin{array}{c}4.22 \pm 3.26 ; 3.99(0 \\
-13.29)\end{array}$ & $\begin{array}{l}9.68 \pm 8.64 ; 5.75 \\
\quad(3.83-33)\end{array}$ & $\begin{array}{c}3.52 \pm 3.74 ; 2.57(0 \\
-11.33)\end{array}$ & $\begin{array}{c}16.23 \pm 32.17 ; 4.3 \\
\quad(1.17-114.5)\end{array}$ & $\begin{array}{c}7.23 \pm 6.25 ; 6.43 \\
(0.71-22.29)\end{array}$ & $\begin{array}{r}187.37 \pm 101.24 \\
155.4(66.5-369)\end{array}$ \\
\hline Chl-a $\left(\mu \mathrm{g} . \mathrm{L}^{-1}\right)$ & $\begin{array}{c}11.64 \pm 7.51 ; 8.56 \\
(3.77-25.69)\end{array}$ & $\begin{array}{c}156.79 \pm 26.1 ; \\
159.00(110.8- \\
203.3)\end{array}$ & $\begin{array}{c}63.32 \pm 27.4 ; 57.62 \\
(14.99-116.82)\end{array}$ & $\begin{array}{c}233.3 \pm 140 ; 210.40 \\
\quad(65.15-460.43)\end{array}$ & $\begin{array}{c}63.6 \pm 29.4 ; 61.15 \\
(26.38-106.71)\end{array}$ & $\begin{array}{c}63.5 \pm 33.0 ; 52.40 \\
(20.38-117.51)\end{array}$ \\
\hline
\end{tabular}

Volume $=$ water volume, Turb $=$ turbidity, Secchi $=$ Secchi depth, $\mathrm{TSS}=$ total suspended solids, $\mathrm{EC}=$ electrical conductivity, $\mathrm{DO}=$ dissolved oxygen, $\mathrm{NO}_{3}{ }^{-}=$nitrate, $\mathrm{TP}=$ total phosphorus, $\mathrm{NH}_{4}^{+}=$ammonium ion, $\mathrm{SRP}=$ soluble reactive phosphorus and Chl-a $=$ chlorophyll-a.

Nitrate $\left(\mathrm{NO}_{3}{ }^{-}\right)$presented in Boqueirão de Parelhas had the highest median in Period II, $200.5 \mu \mathrm{g} . \mathrm{L}^{-1}$; however, in Passagem das Traíras the highest concentrations were found in Period III, $220.9 \mu \mathrm{g} . \mathrm{L}^{-1}$ (Table 2). The highest median values of Chl-a concentrations were recorded in Boqueirão de Parelhas in Period III (61.15 $\left.\mu \mathrm{g} \cdot \mathrm{L}^{-1}\right)$, whereas for Passagem das Traíras they were recorded in Period II (210.4 $\left.\mu \mathrm{g} \cdot \mathrm{L}^{-1}\right)$ (Table 2). Ammonia $\left(\mathrm{NH}_{4}^{+}\right)$showed the highest median value in both reservoirs (BOQ $202.8 \mu \mathrm{g} . \mathrm{L}^{-1}$;

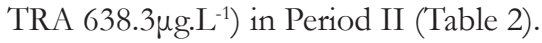

The principal component analysis (PCA) of Boqueirão de Parelhas reservoir (Figure 4A), with ten (10) limnological variables and water volume, explained $63.8 \%$ of the data (axis $1: 42.4 \%$, axis $2: 21.4 \%$ ). The first axis was positively correlated to water volume $(0.80)$ and Secchi transparency (0.93), and negatively correlated to TP (-0.82), TSS (-075), Turbidity (-0.85) and chlorophyll-a $(-0.90)$. The second axis was mainly positively correlated to SRP (0.57) and DIN (0.45), and negatively correlated to $\mathrm{pH}(-0.72)$ and conductivity $(-0.89)$. Axis $1(\mathrm{p}=0.001)$ showed a temporal trend of the sample units according to the consequences of the prolonged drought. On the positive side of this axis were related sample units of the Period I (beginning of the drought), with higher water volume and light (Secchi depth and low turbidity), and lower algal biomass concentrations. On the negative side of this axis were related the sample units of the prolonged drought, Periods II and III, with higher concentrations of total phosphorus, turbidity, total suspended solids and algal biomass. Axis 2 ( $\mathrm{p}$ $=0.001)$ presented a temporal trend according to the drought severity between Periods II and III. On the negative side were sample units from period II, classified as severe to extreme drought by SPI-36, with high values of $\mathrm{pH}$ and electrical conductivity. On the positive side were sample units from period III, classified as mild drought (end of dry period) with high values of dissolved nutrients (SRP and DIN).

For the Passagem das Traíras reservoir, the PCA (Figure 4B) explained $64.14 \%$ of the data (axis 1: $34.74 \%$, axis $2: 29.4 \%$ ). The most important variables in the ordering of axis 1 were: Secchi (0.83), SRP (0.77), pH (-0.77), chlorophyll-a (-0.77), turbidity $(-0.67)$, TSS (-053), dissolved oxygen (-0.51). In relation to axis 2 , the most important variables were: water volume (-0.92), electrical conductivity (0.79), TP (0.73) and DIN (0.63). Axis $1(\mathrm{p}=0.001)$ showed a temporal trend of the sample units according to the intensity of the drought, classified by the SPI-36. On the negative side were sample units of Period II (severe/extreme drought) with higher $\mathrm{pH}$ values, turbidity, DO, TSS and algal biomass. On the positive side were sample unit of Period 3 (mild drought - the end of the prolonged drought) with high Secchi depth and soluble reactive phosphorus. Axis $2(\mathrm{p}=0.001)$ showed a temporal trend of the sample units according to the water volume. On the negative side were sample units of Period I with high water volume. On the positive side segregated the sampling units of Periods II and III, with the consequences of the prolonged drought period, with low water volume and higher values of nutrients (TP and DIN) and conductivity. 
(A)

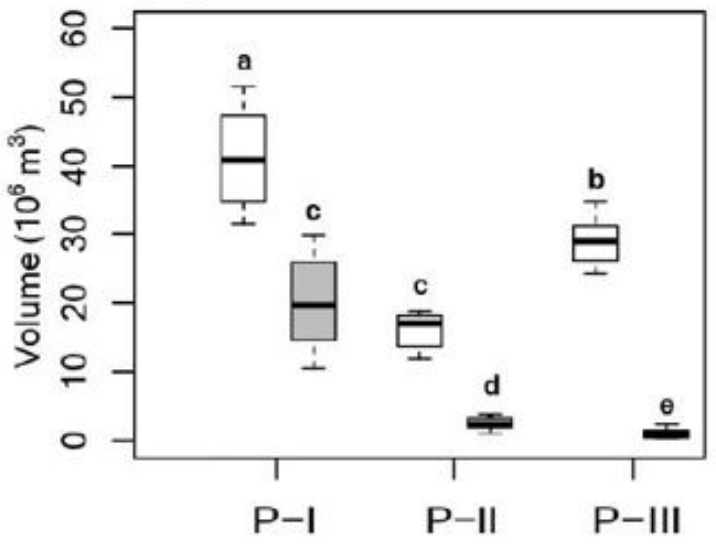

Period

(C)

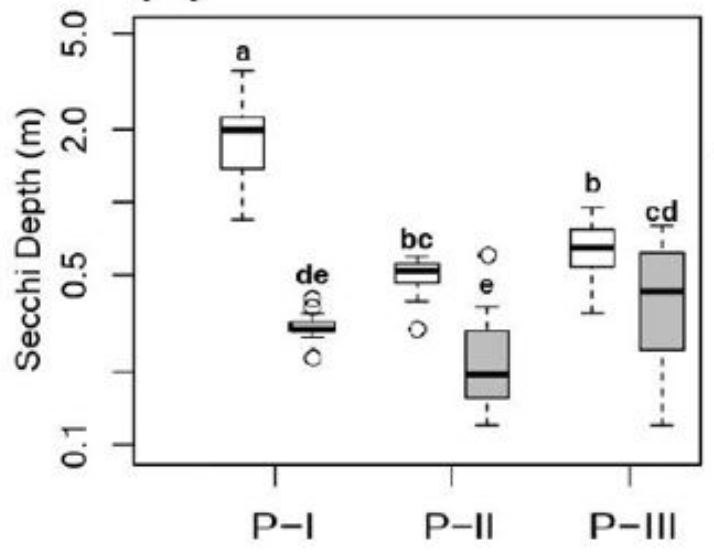

Period

(E)

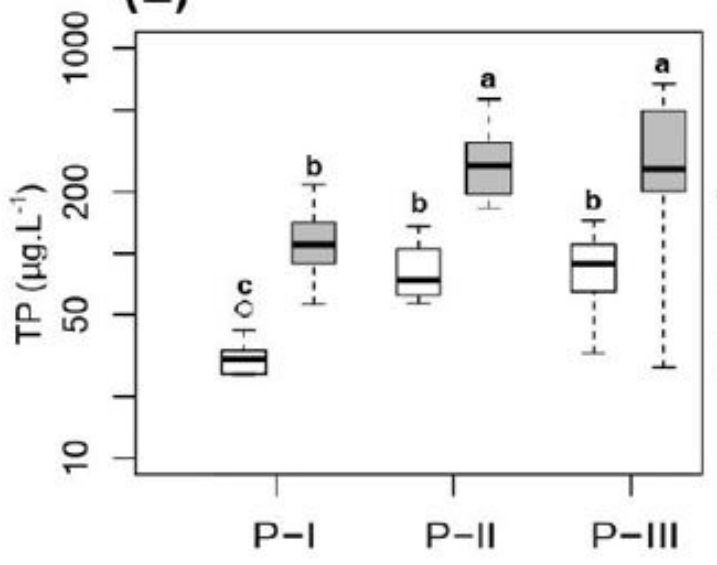

Period
(B)

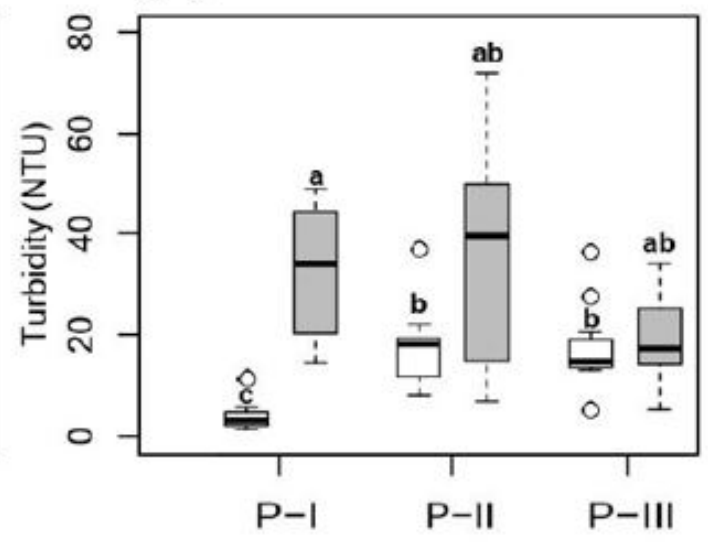

Period

(D)

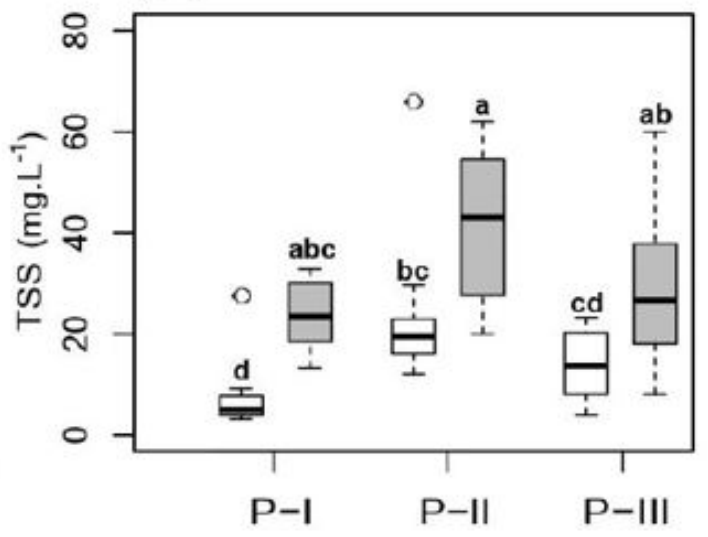

Period

(F)

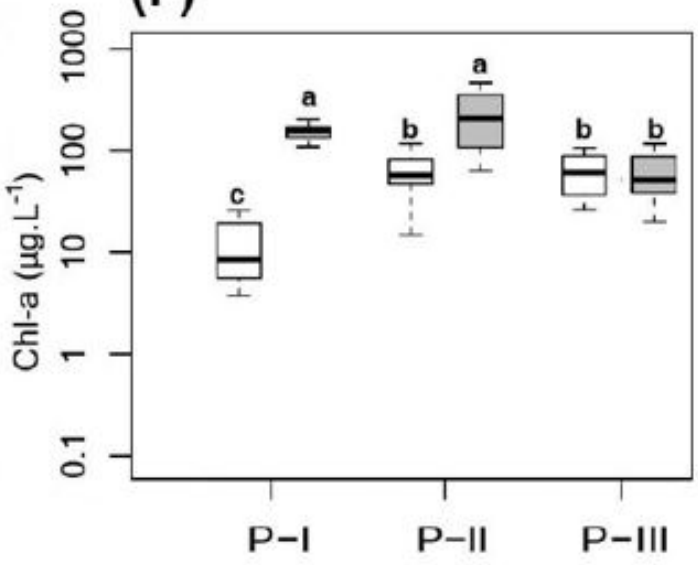

Period

\section{Reservoir \\ Boqueirão \\ Passagem das Traíras}

Figure 3. Box plots whisker, median values (lines inside boxes) and standard deviation (bars) for A) water volume; B) turbidity; C) Secchi depth; D) total suspended solids (TSS); E) total phosphorus (TP); F) chlorophyll-a (Chl-a), during Period I, II and III, in Boqueirão de Parelhas and Passagem das Traíras reservoirs. Means followed by the same letter do not differ from each other by the Kruskal-Wallis test followed by Fisher's post hoc $\mathrm{p}<0.05$. 

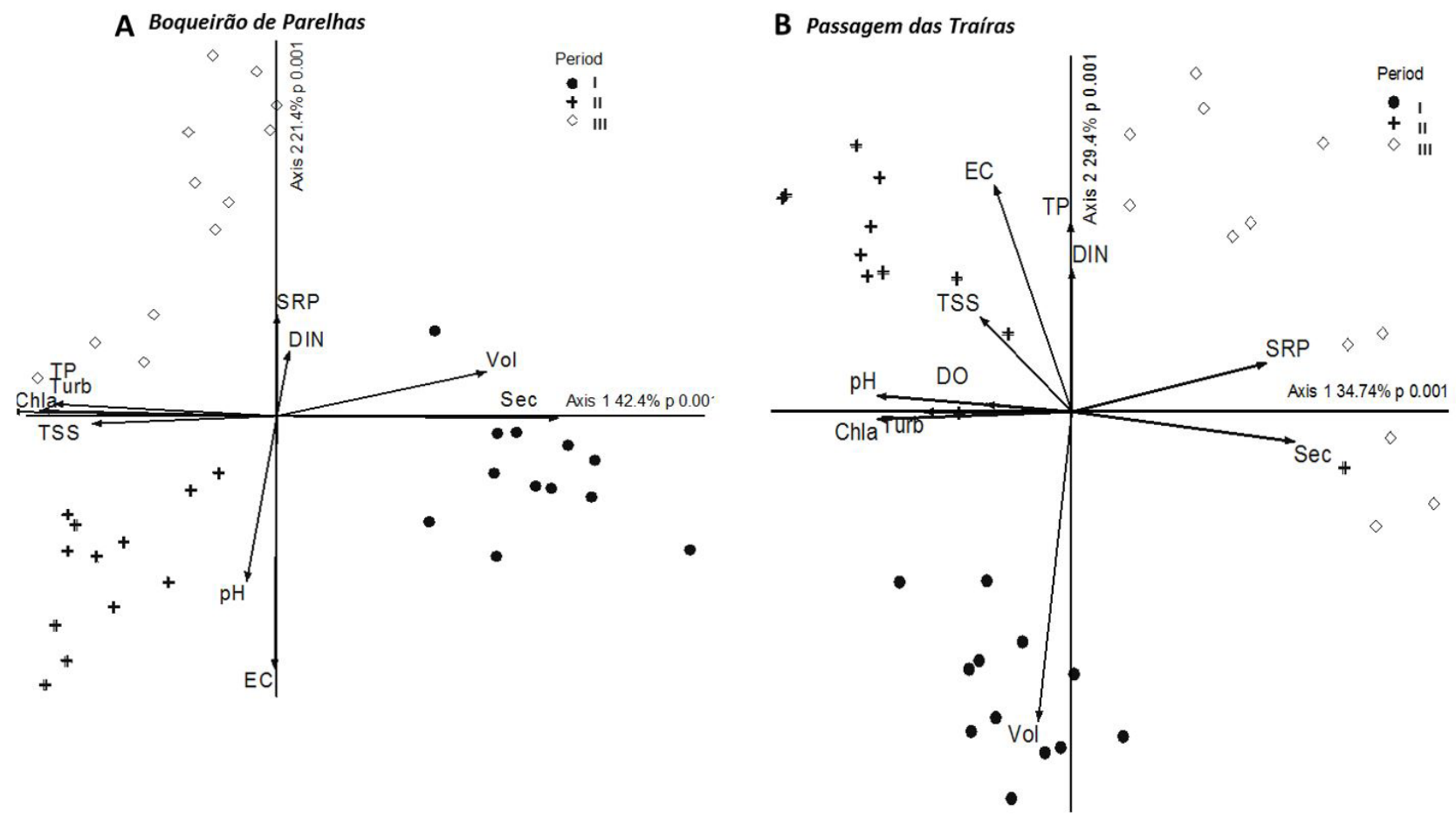

Figure 4. Principal components analysis (PCA) scores applied to environmental variables in Boqueirão de Parelhas (A) and Passagem das Traíras (B) reservoirs. The sample units were according to period classification (Period I, II and III).

Water volume (Vol), Secchi depth (Sec), electrical conductivity (EC), hydrogen potential ( $\mathrm{pH})$, dissolved oxygen (DO), turbidity (Turb), total suspended solids (TSS), total phosphorus (TP), soluble reactive phosphorus (SRP), chlorophyll (Chl-a).

Based on the concentrations of TP and Chl-a to categorize the trophic state of the reservoirs, Passagem das Traíras maintained a eutrophic state throughout all of the study periods, whereas Boqueirão de Parelhas changed the trophic state from mesotrophic (2012) to eutrophic (2014 and 2018/2019) (Figure 5).

\section{DISCUSSION}

In this study a report on the intensification of the eutrophication of reservoirs in Brazil's semiarid region has been offered. Changes in the trophic state have been reported, mainly related to impacts in the increase of nutrients and algal biomass.

The decrease in rainfall, associated with high temperatures, contributed to the intensification of eutrophication with an increase in the concentration of nutrients, chlorophyll concentration, conductivity, and total suspended solids. This pattern was noted in several studies in the same semiarid region during an extreme drought (Roland et al., 2012; Brasil et al., 2016; Gomes, 2016; Costa et al., 2016; Mendonça et al., 2018; Rocha et al., 2018; Figueiredo \& Becker, 2018; Leite \& Becker, 2019; Lacerda et al., 2018; Braga \& Becker, 2020). Despite these studies reported in the semiarid region, little is covered on a larger time scale. The results of these studies, including those from our work, converge with the results of Moss et al. (2011) that reported the conection between climate change and eutrophication. Changes in the precipitation and evaporation regime, allied to high temperatures and caused by climate changes, can aggravate the phenomenon of eutrophication (Moss et al., 2011). Thereby, a negative water balance due to the heat can increase the concentration of nutrients, which increases the mineralization and algal biomass (Moss et al., 2011).

Wiegand et al. (2021) pointed out that the trophic state of the reservoirs, which was already high before the drought (mainly eutrophic and hypereutrophic), the trophic state index of $91 \%$ of the reservoirs increased in the dry period. In our study, three periods during a prolonged drought (2012 to 2019), were highlighted to verify the effects of the intensification of eutrophication caused by the reduction of water volume. Despite not having worked with trophic index as Wiegand et al. (2021), our study found the same patterns working with the trophic state approach by Thornton \& Rast (1993), taking into account the concentration values of TP and algal biomass (chlorophyll-a), as well as other studies in the region reported (Rocha et al., 2018; Braga \& Becker, 2020; Cavalcante et al., 2021; Vanderley et al., 2021).

During the intensification of the drought, as identified in this study, the Boqueirão de Parelhas reservoir showed an accelerated eutrophication process, changing the trophy state from mesotrophic to eutrophic. Meanwhile, the Passagem das Traíras reservoir, classified since the beginning of the study as eutrophic, maintained its trophic state; however, there was an increase in its availability of nutrients with the decrease of its water volume.

With projections indicating greater water deficits in the region where the Boqueirão de Parelhas and Passagem das 


\section{Passagem das Traíras Reservoir}
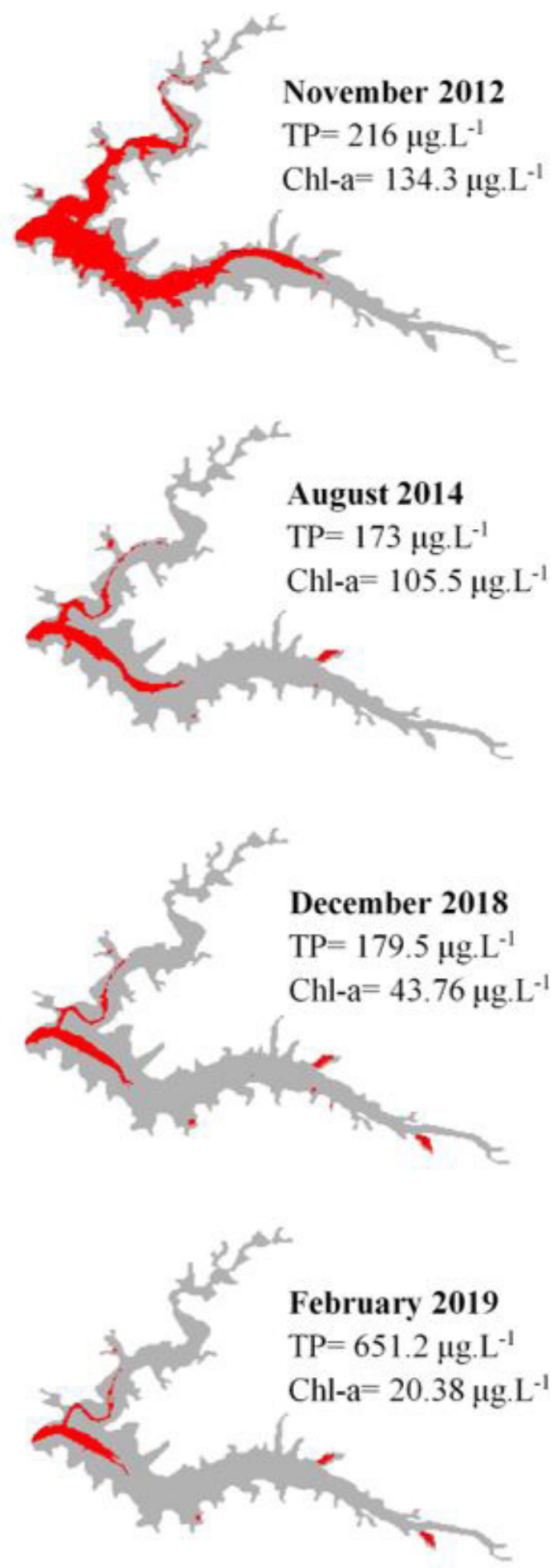

\section{Cartograpic Reference} Coordinate System UTM 24 South Datum SIRGAS 2000

Data Source - USGS

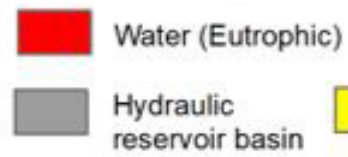

\section{Boqueirão de Parelhas Reservoir}
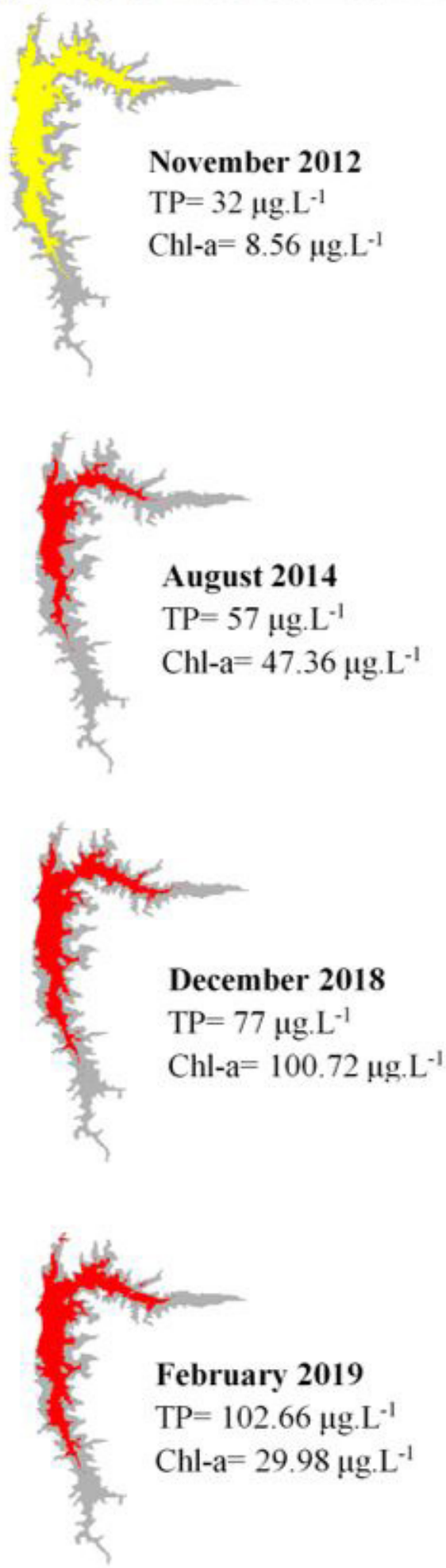

Water (Mesotrophic)

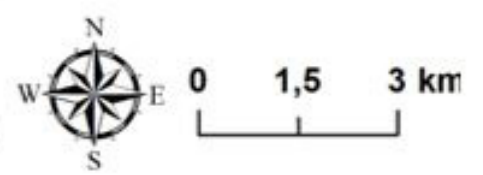

Figure 5. Classification of the trophic state of the Boqueirão de Parelhas and Passage of Traíras reservoirs over the monitored periods, showing the drainage area. Red represents the eutrophic state; yellow represents the mesotrophic state (classification according Thornton \& Rast, 1993). 
Traíras reservoirs are located, it is projected that, over a period of 50 years (2016 to 2065), the water deficit will increase by up to 133\% (Centro de Estudos em Sustentabilidade, 2018). Thus, the trend is that freshwater ecosystems that already have problems related to water quality intensify the symptoms of eutrophication.

The principal component analyses (PCA) of both reservoirs reveled a showed a temporal trend of the sample units according to the consequences of the prolonged drought. The results indicated changes in limnological variables due to the reduction of accumulated water volume, and they demonstrated that prolonged droughts impacted the intensification of eutrophication in both systems.

Although SPI improves the drought severity index, changing from severe-extreme drought of Period II to mild drought of Period III, the water volume, in both systems, were still below 50\% accumulation, mainly Passagem das Traíras, which visibly cannot recover its volume. This pattern is due to the fact that rivers in the region are intermittent (Barbosa et al., 2012). First all, when the rainfall begins, occur the "rewetting phase" of the river. At a delayed time, the reservoir receives the water, and accumulates in the dam (sampling point in our study in both reservoirs). With the lack of precipitation and external supply of nutrients throughout periods of drought, the concentrations of nitrogenous and phosphate compounds tend to increase by the internal loading (Cavalcante et al., 2021), which is potentially related to the high evaporation rate and decomposition of the organic matter (Brasil et al., 2016). For this reason, with water volumes still low in Period III, there are still high nutrients concentrations (as TP) and algal biomass (Chl-a), pattern observed in other studies from the same region (Brasil et al., 2016; Rocha et al., 2018; Wiegand et al., 2021). Also, the prolonged drought led to changes in the chemical conditions of the reservoirs, and it also increased the conductivity and salinity, as has happened in other warm climates, as mediterranean (Jeppesen et al., 2015).

Projections indicating the intensification of extreme events may increase the water deficit and susceptibility of the semiarid region of northeastern Brazil in the face of climate change. Our work can be used to help predict the consequences of extreme drought events in Brazilian semiarid reservoirs, since the results exposed the most recurrent problems with water quality introduced by prolonged droughts. Our findings can be extended to other freshwater ecosystems that have similar characteristics, such as extreme events (especially droughts) and high temperatures, like some semiarid regions around the world.

\section{CONCLUSIONS}

The study reported that prolonged droughts negatively affect water quality in the reservoirs of semiarid regions, which worsens symptoms of eutrophication. A prolonged drought, resulting from the change in the precipitation regime over time, results in changes to limnological variables, which further aggravates the water quality of reservoirs, as shown in both reservoirs we studied. Also has been shown that in Boqueirão de Parelhas reservoir, the trophy state was changed from mesotrophic to eutrophic, while in Passagem das Traíras the eutrophic state remained, but with more intensified symptoms, with higher concentration values of nutrients, solids and algal biomass.

\section{ACKNOWLEDGEMENTS}

We are thankful to the Financiadora de Estudos e Projetos (FINEP) process n ${ }^{\circ} 52009$ and the Conselho Nacional de Desenvolvimento Científico e Tecnológico (CNPq) process number 407783/2016-4 for financial support. We are grateful to the Estudos Limnológicos do Semiárido group (ELISA), especially José Neuciano Pinheiro de Oliveira, Carlos Alberto N. Rocha Junior, Mariana R.A. da Costa, Jurandir de Mendonça Junior, Radmila Salviano, Thaís Lopes Pinheiro, Fernanda Monicceli, Hérika Cavalcante, André Luis da Silva, Pablo Rubim, Daniel Jádson Lima, Fabiana Oliveira Araújo, and all other members (old and new) for technical support with field work and laboratory analyses.

VB also acknowledges continuous funding through a Research Productivity Grant provided by CNPq (process \#308652/20193) and DFS to CNPq for granting the Master's scholarship. We thank Dr. Arthur Mattos, in memoriam, who was coordinator of the FINEP project. The authors declare no conflict of interest.

\section{REFERENCES}

Agência Nacional de Águas - ANA. (2016) Monitor de secas. Retrieved in 2021, July 01, from http://monitordesecas.ana.gov.br/.

Alvalá, R. C. S., Cunha, A. P. M. A., Brito, S. S. B., Seluchi, M. E., Marengo, J. Á., Moraes, O. L. L., \& Carvalho, M. A. (2017). Drought monitoring in the Brazilian Semiarid region. Anais da Academia Brasileira de Ciências, 91(1), 1-15. http:/ / dx.doi.org/10.1590/00013765201720170209.

Alvares, C. A., Stape, J. L., Sentelhas, P. C., Gonçalves, J. L. M., \& Sparovek, G. (2014). Köppen's climate classification map for Brazil. Meteorologische Zeitschrift, 22(6), 711-728. http://dx.doi. org/10.1127/0941-2948/2013/0507.

Alves, L. M., Chadwick, R., Moise, A., Brown, J., \& Marengo, J. A. (2021). Assessment of rainfall variability and future change in Brazil across multiple timescales. International Journal of Climatology, 41(1), E1875-E1888. http://dx.doi.org/10.1002/joc.6818.

American Public Health Association - APHA. 2005. Standard Methods for the Examination of Water and Wastewater (20th ed.). Washington: APHA.

American Public Health Association - APHA. 2012. Standard Methods for the Examination of Water and Wastewater (22th ed.). New York: APHA

Barbosa, J. E. L., Medeiros, E. S. F., Brasil, J., Cordeiro, R. S., Crispim, M. C. B., \& Silva, G. H. G. (2012). Aquatic systems in semi-arid Brazil: limnology and management. Acta Limnologica Brasiliensia, 24(1), 103-118. http://dx.doi.org/10.1590/S2179975X2012005000030.

Bouvy, M., Molica, R., Oliveira, S., Marinho, M., \& Beker, B. (1999). Dynamics of a toxic cyanobacterial Bloom (Cylindrospermopsis raciborskii) in a shallow reservoir in the semi-arid region of 
northeast Brazil. Aquatic Microbial Ecology, 20, 285-297. http:// dx.doi.org/10.3354/ame020285.

Braga, G.G., \& Becker, V. (2020). Influence of water volume reduction on the phytoplankton dynamics in a semiarid $\mathrm{m}$ anmade lake: a comparison of two morphofunctional approaches. Anais da Academia Brasileira de Ciências, 92(1), 1-17. http:/ /dx.doi. org/10.1590/0001-3765202020181102.

Brasil, J., Attayde, J. L., Vasconcelos, F. R., Dantas, D. D. F., \& Huszar, V. L. M. (2016). Drought-induced water-level reduction favors cyanobacteria blooms in tropical shallow lakes. Hydrobiologia, 770(1), 145-164. http://dx.doi.org/10.1007/s10750-015-2578-5.

Bravo, R. Z. B., Cunha, A. P. M. A., Leiras, A., \& Oliveira, F. L. C. (2021). A new approach for a drought composite index. Natural Hazards, 108, 755-773.

Cavalcante, H., Araújo, F., Becker, V., \& Barbosa, J. E. L. (2021). Internal phosphorus loading potential of a semiarid reservoir: an experimental study. Acta Limnologica Brasiliensia, 33, e6. http:/ / dx.doi.org/10.1590/S2179-975X10220.

Cavalcante, H., Cruz, P. S., Viana, L. G., Silva, D. L., \& Barbosa, J. E. L. (2017). Influence of the use and the land cover of the catchment in the water quality of the semiarid tropical reservoirs. Journal of Hyperspectral Remote Sensing, 7(7), 389-398.

Centro de Estudos em Sustentabilidade - FGVces. Escola de Administração de Empresas da Fundação Getulio Vargas - FGV EAESP. (2018) Análise custo-benefício de medidas de adaptação à mudança do clima na bacia bidrográfica dos Rios Piancó-Piranhas- Açu: resumo do projeto. São Paulo: FGV EAESP.

Centro Nacional de Monitoramento e Alertas de Desastres Naturais - CEMADEN.(2019). Sistema de Monitoramento de Seca para o Brasil-Junho/2019. Retrieved in 2020, May 17, from http:/ / www2.cemaden.gov.br/sistema-de-monitoramento-de-seca-parao-brasil-junho2019/.

Costa, M. R. A., Attayde, J. L., \& Becker, V. (2016). Effects of water level reduction in the dynamics of phytoplankton functional groups in tropical semi-arid lakes. Hydrobiologia, 778(1), 75-89. http:/ /dx.doi.org/10.1007/s10750-015-2593-6.

Costa, M. R. A., Menezes, R. F., Sarmento, H., Attayde, J. L., Sternberg, L. S. L., \& Becker, V. (2019). Extreme drought favors potential mixotrophic organisms in tropical semi-arid reservoir. Hydrobiologia, 831(1), 43-54. http://dx.doi.org/10.1007/s10750018-3583-2.

Cunha, A. P. M. A., Zeri, M., Leal, K. D., Costa, L., Cuartas, L. A., Marengo, J. A., Tomasella, J., Vieira, R. M., Barbosa, A. A., Cunningham, C. C., Garcia, J. V. C., Broedel, E., Alvalá, R. C., \& Ribeiro Neto, G. (2019). Extreme drought events over Brazil from 2011 to 2019. Atmosphere, 10(11), 1-20. http://dx.doi.org/10.3390/ atmos10110642.
Dodds, W. K., Bouska, W. W., Eitzmann, J. L., Pilger, T. J., Pitts, L., Riley, A. J., Schloesser, J. T., Thornbrugh, D. J., Pitts, K. L., Riley, A. J., Schloesser, J. T., \& Thornbrugh, D. J. (2009). Eutrophication of U. S. Freshwaters: analusis of potential economic damages. Environmental Science \& Technology, 43, 12-19. http://dx.doi. org/10.1021/es801217q.

Figueiredo, A. V., \& Becker, V. (2018). Influence of extreme hydrological events in the quality of water reservoirs in the semiarid tropical region. Revista Brasileira de Recursos Hidricos, 23(53), 1-8. http://dx.doi.org/10.1590/2318-0331.231820180088.

Gomes, S. S. (2016). Alteração do estado trófico durante um evento de seca prolongada e seus impactos na biomassa algal de um manancial tropical da região semiárida (Masters dissertation). Retrieved in 2020, May 17, from https://repositorio.ufrn.br/jspui/bitstream/123456789/21182/1/ SilvanaSantanaGomes_DISSERT.pdf.

Gummus, V., \& Algin, H. M. (2017). Meteorological and hydrological drought analysis of the Seyhan-Ceyhan River Basins, Turkey. Meteorological Applications, 24(1), 62-73. http://dx.doi.org/10.1002/ met.1605.

Gutiérrez, A. P. A., Engle, N. L., Nys, E., Molejon, C., \& Martins, E. S. (2014). Drought preparedness in Brazil. Weather and Climate Extremes, 3, 95-106. http://dx.doi.org/10.1016/j.wace.2013.12.001.

Intergovernmental Panel on Climate Change - IPCC. (2014). Summary for policymakers. In: Field, C.B., Barros, V.R., Dokken, D.J., Mach, K.J., Mastrandrea, M.D., Bilir, T.E., Chatterjee, M., Ebi, K.L., Estrada, Y.O., Genova, R.C., Girma, B., Kissel, E.S., Levy, A.N., Maccracken, S., Mastrandrea, P.R., \& White, L.L. (Eds.), Climate change 2014: impacts, adaptation, and vulnerability. Contribution of working group II to the Fifth Assessment Report of the Intergovernmental Panel on Climate Change (pp. 1-32). Cambridge: Cambridge University Press.

Jeppesen, E., Brucet, S., Naselli-Flores, L., Papastergiadou, E., Stefanidis, K., Nõges, T., Nõges, P., Attayde, J. L., Zohary, T., Coppens, J., Bucak, T., Menezes, R. F., Freitas, F. R. S., Kernan, M., Søndergaard, M., \& Beklioğlu, M. (2015). Ecological impacts of global warming and water abstraction on lakes and reservoirs due to changes in water level and related changes in salinity. Hydrobiologia, 750(1), 201-227. http://dx.doi.org/10.1007/s10750-014-2169-x.

Jeppesen, E., Kronvang, B., Meerhoff, M., Søndergaard, M., Hansen, K. M., Andersen, H. E., Lauridsen, T. L., Liboriussen, L., Beklioglu, M., Ozen, A., \& Olesen, J. E. (2009). Climate change effects on runoff, catchment phosphorus loading and lake ecological state, and potential adaptations. Journal of Environmental Quality, 38(5), 1930-1941. http://dx.doi.org/10.2134/jeq2008.0113.

Jespersen, A. M., \& Christoffersen, K. (1987). Measurements of chlorophyll-a from phytoplankton using ethanol as extraction solvent. Hydrobiologia, 109, 445-454. 
Kousky, V. E., \& Gan, M. A. (1981). Upper tropospheric cyclonic vortices in the tropical South Atlantic. Tellus, 33(6), 538-551. http:/ / dx.doi.org/10.3402/tellusa.v33i6.10775.

Lacerda, L. D., Santos, J. A., Marins, R. V., \& Silva, F. A. T. F. D. (2018). Limnology of the largest multi-use artificial reservoir in NE Brazil: the Castanhão Reservoir, Ceará State. Anais da Academia Brasileira de Ciências, 90(2), 2073-2096. http://dx.doi. org/10.1590/0001-3765201820180085.

Leite, J. N. C., \& Becker, V. (2019). Impacts of drying and reflooding on water quality of a tropical semi-arid reservoir during an extended drought event. Acta Limnologica Brasiliensia, 31, e15. https://doi. org/10.1590/S2179-975X6918.

Marengo, J. A., \& Bernasconi, M. (2015). Regional differences in aridity/ drought conditions over Northeast Brazil: present state and future projections. Climatic Change, 129, 103-115. http:// dx.doi.org/10.1007/s10584-014-1310-1.

Marengo, J. A., Alves, L. M., Alvala, R. C., Cunha, A. P., Brito, S., \& Moraes, O. L. L. (2018). Climatic characteristics of the 20102016 drought in the semiarid Northeast Brazil region. Anais da Academia Brasileira de Ciências, 90(2), 1973-1985. http://dx.doi. org/10.1590/0001-3765201720170206.

Marengo, J. A., Alves, L. M., Soares, W. R., Rodriguez, D. A., Camargo, H., Riveros, M. P., \& Pabló, A. D. (2013). Two contrasting severe seasonal extremes in tropical South America in 2012: flood in Amazonia and drought in Northeast Brazil. Journal of Climate, 26(22), 9137-9154. http://dx.doi.org/10.1175/JCLI-D-12-00642.1.

Marengo, J. A., Cunha, A. P. M. A., Nobre, C. A., Ribeiro Neto, G. G., Magalhaes, A. R., Torres, R. R., Sampaio, G., Alexandre, F., Alves, L. M., Cuartas, L. A., Deusdará, K. L. R., \& Álvala, R. C. S. (2020). Assessing drought in the drylands of northeast Brazil under regional warming exceeding $4{ }^{\circ} \mathrm{C}$. Natural Hazards, http:/ / dx.doi.org/10.1007/s11069-020-04097-3.

Marengo, J. A., Torres, R. R., \& Alves, L. M. (2016). Drought in Northeast Brazil - past, present, and future. Theoretical and Applied Climatology, 129(3-4), 1189-1200. http://dx.doi.org/10.1007/ s00704-016-1840-8.

Mccune, B., \& Mefford, M. J. (2011). PC-ORD: multivariate analysis of ecological data. Version 6. Gleneden Beach: MjM Software Design.

McKee, T. B., Doesken, N. J., \& Kleist, J. (1993). The relationship of drought frequency and duration to time scales. In: American Meteorological Society (Org.), Proceedings of the 8th Conference of Applied Climatology (pp. 179-184). Boston: American Meterological Society.

Medeiros, C. E. F. S. (2016). Os impactos do uso e ocupação e evento de seca extrema na qualidade da água e do solo de um manancial tropical do semiárido (Masters dissertation). Universidade Federal do Rio Grande do Norte, Natal.
Medeiros, L. C., Mattos, A., Lürling, M., \& Becker, V. (2015). Is the future blue-green or brown? The effects of extreme events on phytoplankton dynamics in a semi-arid man-made lake. Aquatic Ecology, 49(3), 293-307. http://dx.doi.org/10.1007/s10452-015-9524-5.

Melo, A. B. C., Cavalcanti, I. F. A., \& Souza, P. P. (2009). Zona de convergência intertropical do Atlântico. In: I. F. A. Cavalcanti, N. J. Ferreira, M. G. A. J. Silva, \& M. A. F. S. Dias (Eds.), Tempo e clima no Brasil (pp. 25-41). São Paulo: Oficina de Textos.

Mendiburu, F. (2021, June, 05). Package 'agricolae': Statistical procedures for agricultural research. $\mathrm{R}$ package version 1.3-5. Retrieved in 2021, September 02, from http://CRAN.R-project.org/package=agricolae.

Mendonça Júnior, J. R., Amado, A. M., Vidal, O. L., Mattos, A., \& Becker, V. (2018). Extreme droughts drive tropical semi-arid eutrophic reservoirs towards CO2 sub-saturation. Acta Limnologica Brasiliensia, 30, e101. http://dx.doi.org/10.1590/s2179-975x1517.

Moal, M., Gascuel-Odoux, C., Ménesguen, A., Souchon, Y., Étrillard, C., Moatar, F., Pannard, A., Souchu, P., Lefebvre, A., \& Pinay, G. (2019). Eutrophication: a new wine in an old bottle? The Science of the Total Environment, 651, 1-11. http://dx.doi.org/10.1016/j. scitotenv.2018.09.139.

Molion, L. C. B., \& Bernardo, S. O. (2002). Uma revisão da dinâmica das chuvas no Nordeste Brasileiro. Revista Brasileira de Meteorologia, 17(1), 1-10.

Morais, M. D. C., Gan, M. A., \& Yoshida, M. C. (2020). Features of the upper tropospheric cyclonic vortices of northeast Brazil in life cycle stages (in review). International Journal of Climatology, http://dx.doi.org/10.1002/joc.6839.

Moss, B., Kosten, S., Meerhoff, M., Battarbee, R. W., Jeppesen, E., Mazzeo, N., Havens, K., Lacerot, G., Liu, Z., De Meester, L., Paerl, H., \& Scheffer, M. (2011). Allied attack: climate change and eutrophication Inland Waters. Inland Waters, 1(2), 101-105. http:/ / dx.doi.org/10.5268/IW-1.2.359.

Muller, R., \& Widemann, O. (1955). Die bestimmung des nitration in Wasser. Von Wasser, 22, 247-271.

Murphy, J., \& Rilley, J. P. (1962). A modified single-solution method for the determination of phosphate in natural waters. Analytica Chimica Acta, 27, 31-36. http://dx.doi.org/10.1016/ S0003-2670(00)88444-5.

Naselli-Flores, L., \& Barone, R. (2003). Steady-state assemblages in a Mediterranean hypertrophic reservoir. The role of Microcystis ecomorphological variability in maintaining an apparent equilibrium. Hydrobiologia, 502(1-3), 133-143. http://dx.doi.org/10.1023/ B:HYDR.0000004276.11436.40.

Naselli-Flores, L., \& Barone, R. (2005). Water-level fluctuations in Mediterranean reservoirs: setting a dewatering threshold as a management tool to improve water quality. Hydrobiologia, 548(1), 85-99. http://dx.doi.org/10.1007/s10750-005-1149-6. 
Nobre, R. L. G., Caliman, A., Cabral, C. R., Araújo, F. C., Guérin, J., Dantas, F. C. C., Quesado, L. B., Venticinque, E. M., Guariento, R. D., Amado, A. M., Kelly, P., Vanni, M. J., \& Carneiro, L. S. (2020). Precipitation, landscape properties and land use interactively affect water quality of tropical freshwaters. The Science of the Total Environment, 716, 137044. http://dx.doi.org/10.1016/j. scitotenv.2020.137044.

Oliveira, P. T., Silva, C. M. S., \& Lima, K. C. (2016). Climatology and trend analysis of extreme precipitation in subregions of Northeast Brazil. Theoretical and Applied Climatology, 130, 77-90. http://dx.doi.org/10.1007/s00704-016-1865-z.

Reboita, M. S., Gan, M. A., Rocha, R. P., \& Ambrizzi, T. (2010). Regimes de precipitação na América do Sul: uma revisão bibliográfica. Revista Brasileira de Meteorologia, 25(2),185-204. http://dx.doi. org/10.1590/S0102-77862010000200004.

Rocha Júnior, C. A. N., Costa, M. R. A., Menezes, R. F., Attayde, J. L., \& Becker, V. (2018). Water volume reduction increases eutrophication risk in tropical semi-arid reservoirs. Acta Limnologica Brasiliensia, 30, e106. http://dx.doi.org/10.1590/s2179-975x2117.

Roland, F., Huszar, V. L. M., Farjalla, V. F., Enrich-Prast, A., Amado, A., \& Ometto, J. P. H. B. (2012). Climate change in Brazil: perspective on the biogeochemistry of inland waters. Brazilian Journal of Biology $=$ Revista Brasileira de Biologia, 72(3), 709-722. http://dx.doi.org/10.1590/S1519-69842012000400009.

Santos, D. F. (2020). A seca e seus impactos quali-quantitativos na disponibilidade hídrica de reservatórios na região semiárida (Masters dissertation). Retrieved in 2020, May 17, from https:/ / repositorio. ufrn.br/bitstream/123456789/30258/1/Secaimpactosquali_ Santos_2020.pdf.

Schindler, D. W. (2006). Recent advances in the understanding and management of eutrophication. Limnology and Oceanography, 51(1), 356-363. http://dx.doi.org/10.4319/lo.2006.51.1_part_2.0356.

Secretaria de Estado do Meio Ambiente e dos Recursos Hídricos do Rio Grande do Norte - SEMARH. (2019). Retrieved in 2019, Feb 05, from http//www.semarh.rn.gov.br/.

Smith, V. H., \& Schindler, D. W. (2009). Eutrophication science: where do we go from here? Trends in Ecology \& Evolution, 24(4), 201-207. http://dx.doi.org/10.1016/j.tree.2008.11.009.

Soares, M. C. S., Marinho, M. M., Azevedo, S. M. F. O., Branco, C. W. C., \& Huszar, V. L. M. (2012). Eutrophication and retention time affecting spatial heterogeneity in a tropical reservoir. Limnologica, 42(3), 197-203. http://dx.doi.org/10.1016/j.limno.2011.11.002.

Thornton, J. A., \& Rast, W. (1993). A test of hypotheses relating to the comparative limnology and assessment of eutrophication in semi-arid man-made lakes. In: M. Straskraba, J. G. Tundise, \&
A. Duncan (Eds.), Comparative reservoir limnology and water quality management (pp. 1-24) London: Kluwer Academic Publishers. https://dx.doi.org/10.1007/978-94-017-1096-1_1.

Tundisi, J. G., \& Matsumura-Tundisi, T. (1992). Eutrophication of lakes and reservoirs: a comparative analysis, case studies, perpectives. In: M. Cordeiro-Marino (Ed.), Algae and environment: a general approach (pp. 1-33). São Paulo: Brazilian Phycological Society.

Valderrama, J. C. (1981). The simultaneous analysis of total nitrogen and phosphorus in natural waters. Marine Chemistry, 10(2), 109-122. http://dx.doi.org/10.1016/0304-4203(81)90027-X.

Vanderley, R.F., Ger, K. A., Becker, V., Bezerra, M. G. T. A. \& Panosso, R. (2021). Abiotic factors driving cyanobacterial biomass and composition under perennial bloom conditions in tropical latitudes. Hydrobiologia, 848, 943-960. http:/ / dx.doi.org/10.1007/ s10750-020-04504-7.

Viana, C. F. G. (2013). Da Seca como episódio à desertificação como processo: uma questão (não) institucionalizada (Tese de doutorado). Retrieved in 2019, Feb 05, from https://repositorio.unb.br/ handle/10482/13936.

Wiegand, M. C., Nascimento, A. T. P., Costa, A. C., \& Lima Neto, E. (2021). Trophic state changes of semi-arid reservoirs as a function of the hydro-climatic variability. Journal of Arid Environments, 184, 104321. http://dx.doi.org/10.1016/j.jaridenv.2020.104321.

World Bank. (2013). Water resources planning and adaptation to climate variability and climate change in selected river basins in Northeast Brazil. final report on a non lending technical assistance program. Washington, DC: World Bank.

\section{Author's Contributions}

Diógenes Fernandes dos Santos: participated actively of the samplings (2018-2019), data acquisition in the field, chemical determinations of nutrients in the laboratory, and wrote the draft.

Jonathan Mota da Silva: contributed to the interpretation of the results and the manuscript's writing-review and editing.

Vanessa Becker: developed the theoretical framework, conceptualization, and supervised the work. Also got resources to carry out the work and contributed to the interpretation of the results and the manuscript's writing-review and editing.

Editor in-Chief: Adilson Pinheiro

Associated Editor: Ibraim Fantin da Cruz 